\title{
POESIA: A “MÁQUINA DE GUERRA" DO PENSAMENTO
}

\author{
Paulo Petronilio Correia*
}

\begin{abstract}
RESUMO: Articula-se neste artigo uma reflexão sobre a poesia como máquina do pensamento, uma vez que a arte poética desliza na linguagem e nos múltiplos signos da arte e força 0 pensamento. Nesse sentido, busco em Deleuze, filósofo da diferença, algumas contaminações rizomáticas e virtuais para, a partir daí problematizarmos a Poesia como ativadora e potencializadora do pensamento e da gagueira que é a linguagem do poeta. Pensar a poesia e a Filosofia da Diferença em trânsito significa estabelecer um fecundo diálogo com a linguagem gaga de Gilles Deleuze. Escrever sobre o pensamento deleuzeano envolve certa dança diante da política da subjetivação, da criação e da reinvenção da vida. Implica em cartografar sua experiência literária com Marcel Proust e a natureza do Signo. A máquina literária é gaga na medida em que arrasta o pensamento para fora dos sulcos costumeiros da linguagem a leva ao delírio. A experiência com a Linguagem literária se dá nessa gagueira desenfreada que faz de cada escritor-poeta um estrangeiro de sua própria língua. A gagueira, desse modo, é o charme da escritura e do devir-escritor. Sem charme não há vida e não há, certamente, a Diferença. $A$ potência da Diferença é a poesia em trânsito com o pensamento e com a linguagem, pois é esse fecundo trânsito a máquina de guerra do pensamento.
\end{abstract}

PALAVRAS-CHAVE: Pensamento. Signo. Diferença. Gagueira. Poesia.

\section{Introdução}

A questão é o desejo do pensamento (BLANCHOT, 2001, p. 43).

Sempre houve, ao longo da tradição seja poética ou filosófica uma intensa e forte zona de vizinhança e indiscernibilidade entre a poesia e filosofia. $\mathrm{Na}$ linguagem poética de Hesíodo, o princípio era o caos. Instaurava aí o princípio originário da sustentação do Kosmo no qual a palavra era o signo primordial que o poeta utilizava para iluminar o mundo, velando-o e, ao mesmo tempo cuidadosamente desvelando-o através do processo de criação, de invenção e reinvenção da vida. A palavra se tornou o leitmotiv da criação pura da vida através do sopro divino e ela seria o processo por excelência de transfusão cósmica em que o poeta e o filósofo fariam de suas ideias, a essência do

\footnotetext{
`Universidade de Brasília/Faculdade de Planaltina. Imeio: ppetronilio@uol.com.br.
}

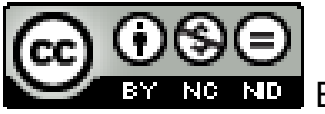

Esta obra foi licenciada com uma Licença Creative Commons

Texto Digital, Florianópolis, v. 9, n. 1, p. 68-94, jan.jjul. 2013. ISSNe: 1807-9288 
pensamento. Se o caos foi instaurado na face da terra foi porque a linguagem, soberana do homem, foi a forma mais cruel e vital que tanto o poeta quanto $o$ filósofo fizeram do pensamento uma "máquina de guerra". Tal máquina caótica fez com que o homem se espantasse consigo mesmo e encontrou, com isso, sua guarida na linguagem. Porta voz do logos o filósofo inquieta e perturba abalando as bases do pensamento. O poeta, antilogos por excelência, é o incorporador e anunciador de um mundo por vir. Uma coisa não podemos negar: a filosofia e a poesia são criações. O poeta e o filósofo, instauradores do caos convidam o mundo a virar o pensamento do avesso através da arte da palavra. A poesia como fonte de pensamento é a forma de trânsito mais sublime com a Filosofia e com outras artes, pois é de natureza dialógica, plural, rizomática e complexa. Tal complexidade se dá devido a sua operação transtextual e polifônica por ser uma dobra que se des/dobra ao infinito. É sob o signo do infinito marcado pela busca da linguagem revolucionária que a poesia opera trazendo o real para o virtual e o virtual para o real. Real e virtual estão co-tecidos formando pregas e dobras, movimentos peristálticos ao infinito da própria linguagem. É a poesia como máquina de guerra do pensamento que se anuncia no seio de uma gagueira desenfreada, na qual a poesia instala em seu ninho rizomático em devir intenso, criando e tecendo seu "charme" no coração do sigo da Diferença, formando um continuum que vai da linguagem esquizo ao pensamento, instaurando na performatividade da linguagem seu ato de fala primordial. Lubrificar as máquinas do pensamento é a ousadia de quem se atreve a falar/fazer poesia, uma vez que falar sobre ela parece ser uma travessia quase ou até mesmo impossível. Talvez o convite seria não em explicar, nem em falar, nem abordar a natureza aporética da Poesia. Mas o convite seria em colocar em jogo e desestabilizar o próprio rumor da linguagem e lutar à luz do dia com a própria língua se quisermos ser afetados pelos murmúrios da linguagem poética. Isso implica em colocar em crise a natureza da poesia e deixar a linguagem falar. Entregaremo-nos à escuta. 


\section{Poesia e linguagem em trânsito...}

"Há sempre a violência do signo que nos força a procurar, que nos rouba a paz" (DELEUZE, 2003, p.14-15). Essa é um das declarações que Gilles Deleuze faz em relação à Arte em geral e em particular à Poesia, pois para o pensador da Diferença, a Poesia é mais poderosa do que a própria Filosofia. No entanto, é a Poesia que promove o encontro, o efeito violento do signo que rouba a paz e nos força a pensar. Desse modo, Deleuze dá uma atenção especial à Poesia. Pensar é o resultado da violência sobre pensamento. A poesia é mais potente que a própria Filosofia uma vez que ela nos força pensar. A poesia é força viva do pensamento que faz com que o homem descubra e redescubra seus tempos. Ela promove a gênese do ato de pensar no próprio pensamento operando por fluxos e cortes permanentes. É a linguagem gaga do poeta que provoca no homem uma transfusão cósmica fazendo-o duplicar a própria linguagem arrastando o pensamento para fora dos sulcos costumeiros e levando- o ao delírio. A poesia é essa dança que pulula no coração da Diferença, pois é o ato poético que provoca uma confluência de sensações, extraindo os afectos das afecções, os perceptos das percepções. A poesia cria e recria uma linguagem múltipla, rizomática, uma vez que, como um rizoma, não começa e não termina. Só tem força e se agita no "meio", no "entre" as palavras. É no "entre" poético que a linguagem se fortalece, se ergue e prolifera. O poeta como porta voz da linguagem é o soberano da Diferença uma vez que é seu estado de pura criação que ele faz com que a linguagem seja duplicada e arrastada ao infinito. A poesia como força viva do pensamento, é um signo a ser decifrado, interpretado. É a capacidade que o poeta tem de fazer da linguagem uma potência do "fora", uma desterritorialização absoluta e, com isso, faz da linguagem uma "máquina de guerra", uma vez que é a força da poesia que violenta o pensamento provocando nele uma espécie de exaltação nervosa. É sob a exaltação nervosa do signo da poesia que o pensamento é capaz de trânsitos para os subterrâneos do pensar múltiplo, plural e polifônico. 
A poesia é a única forma de pensamento capaz de desestabilizar o caos ao infinito. É ela a embaralhadora do pensamento e caotizadora da vida. Ela nos força a pensar por que ela é de natureza rebelde e transgressora. Transgride a moral, a lei, o poder do lugar, a norma, inquietando e desestabiliza o próprio pensamento. É a poesia a experiência desastrosa com a linguagem. Chegar nesse nível de criação é instaurar um mundo que ainda está por vir. Somente o poeta com seu poder de criação poética é capaz de pensar um povo que ainda falta e instaurar, com isso, um pensamento revolucionário. Muito mais que pensar, a poesia aligeira o pensamento e nos impulsiona a acelerar e disparar o pensamento. Cada poesia é uma forma de descarregar a vida e de inventar novas possibilidades de vida. O poeta funde e confunde $\mathrm{o}$ actual e virtual formando uma complexa nebulosa. Nesse trânsito poético-filosófico, os pensadores franceses Deleuze e Guattari são filósofos da fronteira entre o real e o virtual. Pergunta Deleuze: "Por que uma máquina? Pelo simples fato de que a obra de arte, assim compreendida, é essencialmente produtora de certas verdades" (DELEUZE, 2003, p.138). Desse modo, para Deleuze, a Arte é produtora de verdades. A Poesia como uma "máquina de guerra", produz verdades que não estão no céu das ideias se opondo à falsidade, mas produzem verdades na medida em que deciframos, traduzimos, interpretamos suas forças e suas pressões secretas. Elas produzem sentidos e efeitos maquínicos no pensamento, criando, com isso, novos territórios virtuais e novos devires no pensamento. O poeta é sempre gago de sua língua, pois a multiplica, a desterritorializa, a desloca, a desconstrói e cria uma nova imagem do pensamento: um pensamento em Devir, sem imagem.

Ora, pensar a filosofia da diferença no contexto da poesia digital da contemporaneidade implica em perguntarmos em que sentido $O$ pensadores da diferença Deleuze \& Guattari falam em Virtual e até que ponto podemos pensar a Diferença. Em Diálogos, Deleuze testemunha a Claire Parnet que "A filosofia é a teoria das multiplicidades. Qualquer multiplicidade implica elementos reais (actuels) e elementos virtuais" (DELEUZE, 1977, p. 179). Nesse sentido, para Deleuze, o real está recheado de brumas virtuais. Real e virtual estão intimamente ligados, co-tecidos, formando o imenso véu de brumas. O real 
está sempre sendo renovados formando um continnum de imagens virtuais. $O$ plano de imanência comporta simultaneamente o virtual e o atual, desdobrando uma multiplicidade que traduz numa linguagem gaga e esquizo-revolucionária. O trânsito, nesse contexto, é charme de quem escreve, de quem provoca uma política "entre" textos, intertextual ou transtextual. A força da linguagem gaga está na possibilidade de fazer da escrita um rizoma virtual em que o real atua de forma artística e criativa. Desse modo, ser gago da linguagem virtual implica em uma constante busca da criação e invenção de novas possibilidades de vida.

Nesse contexto, a interatividade passa ser o leitmotiv da Diferença, pois "a interatividade remete ao virtual" (LEVY, 1999, p. 80). É desse modo que o ciberespaço virtual se transforma numa potência na contemporaneidade. Tal potência se consuma no rastro da linguagem pois é ela a soberana do homem capaz de duplicar o pensamento e arrastá-lo ao infinito.

Entra em cena a Linguagem e, presa e a ela, a vida, "pois se o teatro duplica a vida, a vida duplica o verdadeiro teatro e isso não tem nada a ver com as ideias de Oscar Wilde sobre a arte". (ARTAUD, 2008, p.127). Isso porque Artaud, na vizinhança e na indiscernibilidade com a Diferença de Gilles Deleuze, não pensa a linguagem separada da vida. O sofrimento de Artaud está no instante em que o espírito não está na vida. O Espírito-órgão que faz duplicar e reduplicar a linguagem pela vida ou a vida pela linguagem o fez dizer abertamente, publicamente "Eu não concebo nenhuma obra separada da vida" (ARTAUD, 2008, p. 207). Essa não aceitação de tal separação é o que leva a escritura a funcionar como uma "máquina de guerra". É assim que Deleuze \& Guattari assumem a Literatura: uma prodigiosa máquina de emitir signos. A máquina literária tem o poder de anunciar a vida que, por sua vez, é desdobrada por que se des/dobra ao infinito que Foucault tanto acreditou ao propor que "desse ruído inquietante que no fundo da linguagem anuncia, logo que se abre um pouco o ouvido, aquilo contra o que se resguarda e ao mesmo tempo a quem nos enderecemos". (FOUCAULT, 2006, p. 52). Referia-se com isso ao inseto de Kafka tão caro a Deleuze por assumir a escritura kafkiana 
como "Literatura menor", pela sua prodigiosa sensibilidade em fazer de sua língua, uma língua maior. Mais ao voltar para a linguagem é desse espelho ao infinito que Foucault chama a atenção. É nesse espelho da linguagem que os duplos se desdobram, pois no infinito da linguagem se multiplica ao infinito. Entre o balbucio e o murmúrio o escritor tem o poder porque ele luta à luz do dia com sua própria língua.

"O rumor é o barulho daquilo que está funcionando bem"' (BARTHES, 2004, p. 94). O que faz a escritura no seu limite desastroso se não rumorejar, balbuciar, gaguejar e vibrar a língua? Rumorejar é, segundo Barthes, fazer ouvir a própria evaporação do barulho. A língua pode rumorejar e gaguejar porque ela é a potência que arrasta a linguagem ao infinito, multiplicando-a e potencializandoa fazendo nascer um povo que falta. O rumor como ruído do gozo plural é a maneira como o signo da arte força o pensamento em direção a algo. É esse signo plural a força viva e ativa do pensamento. É aí que a vida é capaz de ativar o pensamento e este, por sua vez, afirmar a vida. A dupla afirmação entre pensamento e vida é o leitmotiv da gagueira nua e crua da linguagem. A Linguagem só existe porque existe a vida. $\mathrm{E}$ a vida é uma corrente de signos que se cruzam e entrecruzam formando um complexo agenciamento político e maquínico no pensamento.

"Gaguejou", "balbuciou", "soluçou", "escarneceu", "gritou” e, enfim, dançou com a linguagem. São essas expressões que Deleuze assume em sua escritura que oscila entre a Crítica e Clínica literária. Segundo ele, os maus romancistas sentem a necessidade de variar seus indicativos de diálogo, substituindo o "disse" por essas expressões. Mais sem dúvida, Deleuze levou a gagueira do escritor a sério. Foi em Proust que o autor da Diferença esquizo mostrou a importância do escritor se transformar em gago de sua própria língua. "Os belos livros são escritos numa espécie de língua estrangeira". (PROUST, 1988, p. 141).

Ora, como se transformar em estrangeiro de sua própria língua? Em que sentido Kafka, Proust e outros escritores da grande Literatura se transformaram 
em gagos de sua própria língua? Sobre a arte de gaguejar, diz Deleuze, "não é mais o personagem que é gago da fala, é o escritor que se torna gago da língua: ele faz gaguejar a língua enquanto tal' (DELEUZE, 1997, p.138. Grifos do autor). Desse modo, o escritor como soberano da linguagem tem o poder de fazer o crivo no caos e instaurar, a partir daí, uma gagueira desenfreada, prodigiosa e sem limite. O escritor faz gaguejar a língua na medida em que extraem os afectos das afecções, os perceptos das percepções e faz da escritura uma potência de pensamento. Mais que isso, o escritor gago faz pensar o pensamento, pois muito mais que o pensamento é aquilo que dá o que pensar. É a linguagem que pensa a si mesma e produz efeitos maquínicos ao acoplar signos que se desdobram nesse complexo agenciamento que é a Literatura.

Criar é gaguejar a língua. Tal gagueira não está relacionada a um sujeito e nem a um objeto. Nem ao sintagma e nem ao paradigma e sim, a um continuum amorfo linguístico da criação que funde o conteúdo na expressão, a língua na fala, a sincronia na diacronia. A língua é um processo. É todo um devir intenso que povoa a macro e a micro política da linguagem. Não se trata de obedecer a uma regra gramatical. Trata-se de encontrar a linha de fuga, a desterritorialização absoluta da própria linguagem. Trata-se de encontrar a zona de vizinhança e indiscernibilidade possível no meio, intermezzo. Fazer da língua um salto, um diálogo com o de Fora (Dehors), significa driblar os códigos, embaralhar, dificultar, confundir para pensar. Na ficção, Guimarães Rosa, Clarice Lispector, Kafka, Proust, Goethe, Machado de Assis, Dostoievski, Tomas Mann e outros escritores que ousaram na sua língua. Os mesmos são de difíceis compreensões por isso: gaguejaram a sua língua. Inventaram um povo que falta. Esse é o papel de quem escreve: inventar um povo que ainda não existe. Tal invenção está ligada a um processo de pura luta com as palavras. É nessa luta à luz do dia com a palavra que o escritor é capaz de testemunhar a arte e a vida. Carlos Drummond lutou com as palavras, em seu poema $O$ lutador. Tal luta é a empreitada difícil e perigosa de quem faz literatura. Ao escrever, não se escreve com palavras e sim, com fluxos, devires e intensidades. 


\section{Escrever-pensar-poesia: caso de Devir}

A Poesia é a força viva e ativa do pensamento. Ela ativa e activa, forçando o pensamento a pensar. A poesia como uma máquina que força a pensar, faz o pensamento entrar em Devires intensos. É o trânsito com a palavra que faz do poeta um ouvidor da linguagem. Ora, escrever o pensar é fazer uso do pensamento no próprio pensamento. É criar uma linha de feitiçaria com o pensamento. Escrever é tecer uma conversa infinita em forma de prosa sobre o mundo. Escrever-pensar-escritura forma uma trança inseparável, uma vez que a escritura deve ser sedutora na medida em força-a-pensar. Ela deve ser primeiro no pensamento como potência, como fluxo e corte permanente. Em boa parte de sua escritura esquizo-revolucionária, Deleuze problematiza a escrita. A escrita não se separa do Devir, pois é nela que esses devires se encadeiam. É nesse sentido que é impossível falar da linguagem sem falar da escrita. O que é escrever para Deleuze? O autor não demora em responder:

\footnotetext{
Escrever é um caso de devir, sempre inacabado, sempre em vias de fazer-se, e que extravasa qualquer matéria vivível ou vivida. É um processo, ou seja, uma passagem de Vida, que atravessa o vivível e o vivido. A escrita é inseparável do devir; ao escrever, estamos num devir-mulher, num devir-animal ou vegetal, num devir-molécula, até num devir imperceptível (DELEUZE, 1997, p.11).
}

Com isso, Deleuze abre sua cena em Crítica e Clínica afirmando que a linguagem é inseparável dos devires da Vida. Escrever tem uma relação muito forte com o estado clínico do pensamento. Fazer crítica e escrever não significa impor uma forma, uma vez que a Literatura está do lado do informe, do deviranimal até o devir-imperceptível. A escrita atravessa toda matéria vivida e vivível porque escrever não é contar suas próprias lembranças, suas histórias ou neuroses. Não se escreve com palavras e sim, com afectos e perceptos.

Escrever é exercitar a zona de vizinhança e indiscernibilidade com 0 pensamento de tal forma que não é possível mais distinguir-se de uma mulher, de um animal, de uma molécula. É na escritura que se desdobra a linguagem em uma potência de fluxos, devires e intensidades. É daí que o escritor, gago 
de sua língua é capaz de testemunhar a Vida. Ao ter a saúde como Literatura, - escritor faz a língua vibrar e arrasta-a ao delírio, ao estado clínico da linguagem. "Do que viu e ouviu, o escritor regressa com os olhos vermelhos, com os tímpanos perfurados" (DELEUZE, 1997, p.14). Essa experiência-limite com a linguagem fez de Deleuze um escritor gago do pensamento da Diferença. A escritura gaga é desastrosa por excelência por que revela seu fora mais dentro que o próprio dentro. Ou, como pretendeu Piero Eyben, "A escritura como uma espécie de crime a ser cometido de fora da linguagem, uma corrupção de seu dentro" (EYBEN, 2012, p. 79. Grifos do autor). Talvez seja por isso que o autor de Senão ctônica, escritura: verdade e negrume se coloca na vizinhança e se instala na crueldade, na vibração e no ritmo de Artaud-Derrida ao testar a nossa vibração sonora e nos colocarmos à escuta da linguagem em cena. É nesse desastre da inquietação da linguagem que Derrida se instalou ao receber hoje "um impulso espantoso de uma inquietação da linguagem" (DERRIDA, 2002, p.12). Uma inquietação da linguagem na própria linguagem. A linguagem como inquietação, é a gênese da Diferença. Gaguejar a língua dessa forma significa ter uma experiência-limite na inquietação da linguagem. Fazer da linguagem uma inquietação permanente significa colocar a língua em variação contínua e vibrá-la de outra forma a ponto de pensar um povo que ainda não existe.

Desse modo, a Diferença encontra sua gênese no ato de pensar no pensamento. Escrever o pensamento é torná-lo Vida. Ou o pensamento é a própria potência vital. Cada escritor cria para si a sua língua, gagueja-a, arrasta-a ao delírio e volta com os olhos vermelhos e com os tímpanos perfurados. Machado de Assis, certamente regressou com os olhos de ressaca daquilo que viu e viveu enquanto experiência desastrosa com a linguagem. Guimarães Rosa foi quem, certamente, embaralhou os códigos da sua língua e fez vibrar uma terceira margem do pensamento ao potencializar uma escritura do "sertão" como signo da Diferença. A escritura desse modo, é um complexo agenciamento maquínico que emite signos vitais. 
"Eu lhes disse que não tenho mais a minha língua, mais isto não é razão para que vocês persistam, para que vocês se obstinem na língua" (ARTAUD, 2008, p. 210). Uma sensação de ser estrangeiro de sua língua significa arrastá-la a um devir-imperceptível. Não ter mais a sua língua de origem implica em arrastá-la para fora da sintaxe e da morfologia e gaguejá-la e acreditar, como Artaud, que a inspiração existe, embora, segundo ele, toda escritura é uma porcaria e, especialmente a escritura de nosso tempo em que todo mundo é um porco. Ora, como vibrar diante de toda essa porcaria que tenta nos afetar na contemporaneidade? Barthes, para quem a vibração se transformou em um rumor como forma de recriação da linguagem, pensa a escrita como arte de levantar questões e não de Ihes responder ou as resolver. Ela tem o direito, inclusive, de deixar algo em suspenso. Mas o autor do Grão da Voz não deixa de criar rumores sobre a língua: "E a língua, pode rumorejar? Falada, ela permanece, parece condenada ao balbucio; escrita, ao silêncio e à destinação dos signos; de qualquer modo, fica ainda demasiado sentido para que a linguagem realize um gozo que seria próprio da matéria." (BARTHES, 2004, p. 95). Quando falada, a língua está condenada ao balbucio enquanto a escrita está fadada ao silêncio destinado à força dos signos. Rumorejar, balbuciar e gaguejar a língua é o ápice, o gozo e a plenitude da Linguagem. É esse gozo a força viva do Pensamento uma vez que ele é forçado a esses balbucios e rumores que fazem parte da própria inquietação da Linguagem. Conseguir rumorejar a língua e fazê-la funcionar na máquina literária, é a própria realização do gozo diante da escritura. "O rumor é o barulho daquilo que está funcionando bem" (BARTHES, 2004, p. 94). Desse modo, fazer funcionar bem uma máquina literária implica em colocar em funcionamento esses rumores que são esses barulhos-limites com a linguagem, um "barulho impossível" que é o gozo plural. Esse barulho-limite em forma de rumor é o signo da Diferença propriamente dita. Sem esse barulho não existe a gagueira.

Assim, ser gago, é ter uma experiência-limite com esse barulho e esse não dito ensurdecedor que é a Linguagem. A inspiração certamente só existe para quem de fato é um gago de sua língua. Diz Deleuze: "Conseguir gaguejar em sua própria língua, é isso um estilo. É difícil porque é preciso que haja 
necessidade de tal gagueira. Ser gago não em sua fala, e sim ser gago da própria linguagem" (DELEUZE, 1998, p.12). É assim que Deleuze insiste na política da gagueira no ato da composição da escritura. Ser gago da linguagem implica colocar a língua em devir, na corda bamba. Deixar a língua vazar, correr entre fluxos e cortes permanentes. Traçar uma linha de fuga na sua própria língua. Desterritorializá-la. Deleuze cita grandes exemplos de escritores que conseguiram fazer um uso maior da sua língua menor, gaguejando-a como Kafka, Beckett, Gherasim Luca, Godard e faz referência a Gherasim Luca por ter sido um exemplo de poeta entre os grandes que inventou uma gagueira prodigiosa, a sua. Inventar para si a sua língua e emitir prodigiosos e violentos signos, é o desafio de quem experimenta a arte da escrita e confecciona um escrita arte ou uma "pop escrita".

A escrita para Deleuze tem a ver com um certo charme. Em Diálogos, o autor salienta que, como na vida, existe uma gagueira vital que é o charme de alguém. $O$ charme é fonte de vida e os que não têm charme não têm vida, são como mortos. Fernando Pessoa é, certamente um charmoso na arte de provocar a potência do Desassossego. Com sua língua gaga, o autor violenta o pensamento e rouba a paz, provocando um abalo, uma espécie de "exaltação nervosa".

"Escrever, então, passa a ser uma responsabilidade terrível" (BLANCHOT, 2001 , p. 9). Escrever é uma terrível responsabilidade por que a escrita tem a exigência de criatividade, uma vez que ela é convocada a desfazer o discurso e transgredir a Lei, inclusive a sua própria Lei. É a partir daí que Blanchot toma a discussão da escrita como fio condutor para se tecer uma conversa infinita. Escrever é a maior violência porque existe um jogo insensato da escrita que vaza e que faz do Livro uma máquina, uma potência e, da escritura, a força viva do pensamento. É nesse sentido blanchotiano que a escrita exige a descontinuidade. Dessa forma, que "a questão é o desejo do pensamento" (BLANCHOT, 2001, p. 43). A escritura é o desejo do pensamento por que o que ela reivindica é o pensamento ao infinito. É essa atividade plástica do pensar o pensamento a gênese e o charme da Diferença. Ora, ao se posicionar 
diante da questão mais profunda, a mesma está no plano do pensamento e do movimento, pois para o escritor do desastre, "a questão é movimento, a questão de tudo é totalidade de movimento de tudo" (BLANCHOT, 2001, p. 42). A questão transforma-se no movimento por que ela se mantém infinitamente. Daí porque, para ele, a resposta é a desgraça da questão. A resposta é desgraçada porque tira da questão a possibilidade de questionar, isto é, buscar, sondar, ir ao fundo, trabalhar o fundo. Essa é a tarefa do pensamento: desejar a si mesmo e, para isso, tem exigência de descontinuidade.

Escrever com Deleuze, a partir dele, é fazer o pensamento funcionar de outra forma e instaurar uma topologia do pensamento e uma invaginação do fora. É pensar por estratos, linhas de fuga, buracos negros, dobras, rizomas, ritornelos. É inventar novos territórios desertos, estriados, lisos. É criar um pensamento que nunca foi e nunca será. É criar uma nova imagem do pensamento. Um pensamento sem imagem. Pensamento vampiro por excelência. É o devir-intenso do pensamento. É como uma bruxa que pega sua vassoura e vai para longe. Para o deserto, como fez Guimarães Rosa que começou o sertão "Nonada" e nos fez "remexer vivos" com sua escritura diabólica. Pensar o impensado é o maior desafio de quem quer fazer a Diferença. Viajar para a ilha deserta e, com seus signos malditos da escrita, roubar a paz dos Idiotas que vivem na terra. Rir de nós mesmos e dos doutores da finalidade da existência.

\section{Signo e literatura menor: potências do pensamento}

Ora, é na leitura deleuzeana de Kafka que vemos o autor problematizar a noção de literatura menor. Afinal, o que isso quer dizer? Deleuze esclarecenos: "Uma literatura menor não pertence a uma língua menor, mas, antes, à língua que uma minoria constrói numa língua maior” (Deleuze, 2002, p. 38). Desse modo, para Deleuze, a Literatura menor está relacionada a uma minoria que usa, cria e recria a língua fazendo da mesma uma língua maior. São três conceitos que se acoplam nesse agenciamento literário que une conteúdo e expressão: a linguagem, o político e o colectivo. No entanto, uma das 
características da literatura menor, para Deleuze, é que nela tudo é político, pois todas as questões individuais têm uma forte relação com a política. É desse modo que, segundo Deleuze:

\begin{abstract}
É a literatura que se encontra carregada positivamente desse papel e dessa função de enunciação coletiva e mesmo revolucionária: a literatura é que produz solidariedade activa apesar de cepticismo; esse o escritor está à margem ou à distância de sua própria comunidade, a situação coloca-o mais à medida de exprimir outra comunidade potencial, de forjar os meios de uma outra consciência e de uma outra sensibilidade (DELEUZE, 2002, p. 40).
\end{abstract}

É dessa maneira que Deleuze encara a Literatura: a partir dessa trilogia linguagem-político-colectivo. Quando Deleuze aborda a obra de Kafka, o autor a encara como uma Toca, um rizoma de entradas múltiplas. A Literatura como uma máquina rizomática que arrasta o pensamento do leitor ao infinito é uma força. Assim, se compreende a Literatura como um verdadeiro agenciamento maquínico que força a pensar e aprende-se que o pensamento se desdobra das margens da escrita. Quando se embaralha os códigos e forçamos a pensar de outra forma, surge o impensado. Ao se debruçar na máquina literária de Kafka, Deleuze \& Guattari assumem que existe uma matéria sonora, a musiquinha de Kafka, pois para eles, "a intrusão do som faz-se muitas vezes em ligação com o movimento de levantar ou endireitar a cabeça: o rato de Josefina; os cãezinhos músicos" (DELEUZE, 2002, p. 21). É todo um bloco de Devir que povoa a máquina literária de Kafka. O escritor faz uso maior da sua língua ao gaguejá-la. O devir-animal de Kafka metamorfoseado num gigantesco inseto em sua Matamorfose. O som alado, a musiquinha, o som puro e intenso que vem do campanário e da torre do castelo, formando um bloco sonoro. Por isso que Deleuze, ao se debruçar na Metamorfose aponta que o som primeiro intervém de um ato de piar que arrasta a voz de Gregório e batalha a ressonância das palavras. É nesse sentido que o que de fato interessa a Kafka é essa matéria plástica e sonora. Talvez seja por isso que Deleuze nos ensinou a maneira com a qual devemos aprender a ler um Livro:

A boa maneira para se ler hoje, porém, é a de conseguir tratar um
livro como se escuta um disco, como se vê um filme ou um programa
de televisão, como se recebe uma canção: qualquer tratamento do
livro que reclamasse para ele um respeito essencial, uma atenção de 
outro tipo, vem de outra época e condena definitivamente o livro (DELEUZE, 1998, p. 11).

Cada Livro é uma dobra vinda de outras dobras e que nunca se desdobra completamente. Isto é fato. O Livro, como um agenciamento maquínico, éticoestético e político, conserva em si um bloco de sensações e fortes zonas de devires. Ler um Livro como escutar um disco implica em se colocar à escuta da própria linguagem. Cada palavra é uma canção. É nesse sentido que de cada escritor é preciso dizer "o escritor como vidente e ouvidor, finalidade da literatura: é a passagem da vida na linguagem que constitui as Ideias" (DELEUZE, 1997, p.16-17). É desse modo que cada escritor transforma-se em gago de sua língua. Quando se transforma em vidente e ouvidor, atravessando todas as raças, todos os povos e todas as tribos. Quando o escritor é obrigado a fabricar para si a sua língua ele entra em estado clínico e, com isto, escreve para um povo que ainda não existe. Cada escritor é um colorista, um ouvidor, um músico das palavras.

Habitar a ilha deserta do pensamento da Diferença implica em ter um certo charme para gaguejar a própria língua. Diz, Deleuze, "É como na vida. Há na vida uma espécie de falta de jeito, de fragilidade da saúde, de constituição fraca, de gagueira vital que é o charme de alguém"( DELEUZE, 1998, p.13). Ao gaguejar a sua língua, o escritor revela seu devir-charmoso como escritor. A gagueira vital é a própria máquina literária. "A vida não é sua história; aqueles a que não têm charme não têm vida, são como mortos" (DELEUZE, 1998, p.13). É o charme a potência de cada um. Não ter charme é não ter vida. É o encontro com o desastre criativo que dá vida ao escritor. É a partir desse charme que o escritor revela sua potência através das palavras como ouvidor, colorista e maldito da linguagem. Por isso Deleuze \& Guattari chegam a afirma em O que é a Filosofia que "O escritor torce a linguagem, fá-la vibrar, abraça-a, fende-a, para arrancar os perceptos das percepções, o afecto das afecções, a sensação da opinião - visando, esperamos, esse povo que ainda não existe." (DELEUZE; GUATTARI, 1992, p. 208). Desse modo, o escritor transforma-se em soberano da linguagem. Tal relação de soberania se dá quando ele torce a abraça a linguagem fazendo-a vibrar, arrancando os afectos das afecções e os 
perceptos das percepções. Vibrar a língua implica em gaguejá-la e isto é condição de possibilidade para que o escritor invente um povo que ainda não existe e crie seu charme no processo de escritura.

A Literatura como arte da diferença, produz efeitos de signos capazes de revelar ao mesmo tempo sua unidade e seu surpreendente pluralismo. $O$ aprendizado dos signos se dá no encontro, numa coerção, numa força, num abalo, num arrombamento em forma de violência ao pensamento. Diz-nos Derrida, sobre a linguagem que, "sonhar reduzi-la a isso é sonhar com a violência" (Derrida, 2002, p.12). Tal signo da violência vem de fora e rouba a paz. A violência é o próprio fora que se traduz como força ou potência. Isso porque, nas palavras de Blanchot:

Toda palavra é uma violência, violência tanto mais temível quanto secreta e o centro secreto da violência, violência que se exerce já sobre aquilo que a palavra nomeia e que ela não pode nomear senão retirando sua presença- sinal, nós o vimos, de que a morte fala (essa morte que é poder) quando falo (BLANCHOT, 2001, p. 86).

A violência da palavra é a linguagem no seu limite, na sua intensidade criadora e criativa. A escritura, ao emitir signos, confere a literatura uma prodigiosa máquina que é pura violência ao pensamento. Em Proust e os Signos Deleuze experimenta o pluralismo do sistema de signos emitidos pela Recherche. Os signos mundanos e amorosos convergem nos signos da arte. É dessa maneira que, para Deleuze, o aprendizado se dá no encontro com algo que força - apensar. "O signo sensível nos violenta: mobiliza a memória, põe a alma em movimento; mas a alma por sua vez, impulsiona o pensamento, Ihes transmite a pressão da sensibilidade, força-o a pensar a essência como a única coisa que deve ser pensada" (DELEUZE, 2003, p. 94). Dessa maneira, Deleuze pensa a natureza dos signos da arte apelando assim para certa sensibilidade diante dos signos da arte, de suas pressões secretas. O aprendizado se dá no acaso de um encontro com algo que força a pensar, que violenta e provoca um abalo, uma espécie de exaltação nervosa. 
Segundo Deleuze, a obra de Proust não consiste na busca da memória, nem na lembrança, ainda que involuntária. É certo que a memória intervém como meio da busca, mas não é o meio da busca do tempo mais profundo; e o tempo passado intervém como uma estrutura do tempo, mas não é a estrutura mais profunda. É preciso algo material que remetem a memória o relato de um aprendizado de um homem. Aprender diz respeito essencialmente aos signos.

\section{Da linguagem esquizo ao pensamento: atos de fala e performatividade}

Em Deleuze, a linguagem vaza e entra em devir. A linguagem antecipa pensamento e ação e se declara suficiente. Uma linguagem esquizorevolucionária brota da força dos signos. Nas mãos do professor Gilles Deleuze, fazemos uma pergunta inevitável e necessária que devemos fazer sobre esse Deleuze do segundo volume de Mil Platôs, que trata de alguns Postulados da Linguística, apoiado na concepção de regimes de signos, é saber contra quem Deleuze escreve quando fala de linguística e qual foi de fato sua contribuição à filosofia da linguagem e à Linguística. Para isso, precisamos perguntar o que Deleuze compreende por linguagem e qual a origem de suas indagações. Parece-me que não iremos chegar a muitas conclusões se enfrentarmos a vasta biblioteca de Deleuze sobre a Linguística para compreendermos do que ele de fato está falando, pois ele dialoga com diferentes teóricos em vários momentos de sua escrita. Mas acredito que é possível, a partir do ponto de vista austiano, tentar compreender sua relação com os atos de fala e sua performatividade, pois Austin em sua Filosofia da linguagem inaugura a concepção de atos de fala no chamado contexto da "virada linguística", inserindo-se, segundo Danilo Marcondes de Souza Filho, na tradição britânica da filosofia analítica. É contra um grande número de estudiosos ligados à problemática da consciência e à noção de representação que Austin começa a se movimentar.

Daí, essas questões vêm a ceder lugar não mais para uma relação entre sentido e referência como pensava Frege, a noção de conteúdo semântico como foi abordado por Russell, mas agora temos em mira o conceito de 
significado. Com os estudos austianos, cai por terra a concepção de verdade que é um conceito fundamental da tradição da semântica clássica e passa a ser substituído pela noção de "eficácia do ato", de sua felicidade, ou de suas condições de sucesso. A radical separação entre linguagem e mundo parece sofrer um profundo abalo. Então, o que de fato muda com a concepção austiana de linguagem? Ora, é evidente que em "Quando Dizer é Fazer", Austin nos coloca diante da concepção de que a linguagem deve ser compreendida essencialmente como uma forma de ação e não de representação da realidade. Sendo assim, a história da linguística toma um outro rumo com o pensamento de Austin e, com Deleuze, há uma outra concepção de linguagem, em termos esquizofrênicos. Com Deleuze corremos o risco de falar em língua, pois pode nos dar a entender que existe a fala do outro lado. Por isso, vamos falar unicamente, tratando-se de Deleuze, em linguagem. O grande paradigma deleuziano começa quando quebra as dicotomias e nos posiciona diante de uma linguagem que a todo o momento nos ordena.

Estamos falando então do surgimento de um novo paradigma teórico que passa a encarar a linguagem como uma ação, ou melhor, do ponto de vista da forma de atuação sobre o real e não de uma mera representação ou correspondência com a realidade. Eis aí uma das consequências básicas desta nova visão proposta por Austin. O "campo semântico" passa a ser visto sobre o ângulo de adjetivos que imperam no método austiano perante uma ética calcada na responsabilidade decorrente de uma ação. Assim, para tentarmos falar em termos linguísticos a partir dessa nova concepção austiana, é preciso nos desprender de qualquer concepção ética abstrata ou até mesmo de conceitos amplos como responsabilidade, ação, vontade, e outras concepções éticas do tipo kantiana, pois essa está voltada para uma ação por dever. A ética aqui é fundamentada em usos abusivos de advérbios tais como "voluntariamente", "deliberadamente", "acidentalmente", "inadvertidamente". A importância do uso desses advérbios na construção da máquina austiana tem sua importância pelo fato de qualificarem ou determinarem o termo "ação". É importante sermos cuidadosos nessa palavra porque ela não tem o propósito 
de designar uma formulação abstrata. Tem sim, um caráter político e semiótico. Os regimes semióticos somente passam a ter sentido quando, inseridos nessa ética calcada na responsabilidade decorrente de uma ação.

Assim, a forma de atuação sobre o real torna mais evidente na teoria austiana, pois a análise da sentença deve ceder o lugar à análise do ato de fala, do uso da linguagem em determinado contexto, com uma determinada finalidade e de acordo com certas normas de convenções. Deixamos de lado a análise da linguagem baseada na estrutura da sentença com toda gama de predicados, ou até mesmo a referência $S$ é $P$, ou o sentido e referência a la Frege, mas dentro de uma semiótica performativa, sermos capazes de nos orientar para os atos de fala, encarando assim, a linguagem como uma forma de realizar atos.

No entanto, Austin cria uma teoria inovadora abrindo novos horizontes de discussões tanto em Linguística quanto em Filosofia da Linguagem. Apoiado nas teses de Austin, Deleuze nos explica que a linguagem não é de natureza comunicativa nem informativa, ou melhor, ela não informa e nem comunica. $O$ que faz então a linguagem? Ela transmite palavras de ordem. Assim:

\footnotetext{
As palavras de ordem não remetem aos enunciados por uma obrigação social. Não existe enunciado que não apresente esse vínculo, direta ou indiretamente. Uma pergunta, uma promessa, são palavras de ordem. A linguagem só pode ser definida pelo conjunto de palavras de ordem, pressupostos implícitos ou atos de fala que percorrem uma língua em um dado momento (DELEUZE, 1995, p.16).
}

Ora, se a linguagem somente pode ser definida pelos atos de fala, a mesma somente pode ser compreendida em termos de ação. A máquina abstrata da língua realiza-se quando fazemos dos performativos e constatativos um núcleo central dos regimes de signos ou da semiótica. No entanto, quando Deleuze nos fala de um certo caráter social da enunciação, ele está nos dizendo que a mesma remete-nos a "agenciamentos coletivos". Sendo assim, o ato de fala não se separa da realidade, pois ao analisar uma determinada linguagem, nosso papel não é simplesmente analisá-la como tal e sim, fazer uma investigação do contexto social e cultural no qual é usado, pois não devemos esquecer que a linguagem é uma prática social concreta, inseparável do 
mundo e não como se houvesse uma barreira separando o sintagma do paradigma, a sincronia da diacronia e até mesmo a língua da fala que desde a máquina saussuriana passou a existir, nos contagiando com dicotomias fortemente marcadas pelo signo linguístico do conceito e da imagem acústica dentro de uma corrente inteiramente arbitrária.

Quando Deleuze \& Guattari iniciam os Postulados de Linguística ${ }^{1}$ afirmando que a professora não se questiona quando interroga um aluno, é porque ela não se envolve nessa máquina de tal maneira que esquece que existe uma profunda trança entre o homem e a língua. Assim, passa a existir uma forte relação entre subjetividade e linguagem. Benveniste, consciente de que o homem se constitui como sujeito ao encarar a linguagem como a única que 0 fundamenta na realidade, como pertencente da natureza humana nos ensina que,

\begin{abstract}
Não atingimos nunca o homem separado da linguagem e não o vemos nunca inventando-a. Não atingimos jamais o homem reduzido a si mesmo e procurando conceber a existência do outro. É um homem falando que encontramos no mundo, um homem falando com outro homem, e a linguagem ensina a própria definição de homem (BENVENISTE, 1991, p. 285).
\end{abstract}

Em outras palavras, assim como Austin, Benveniste ${ }^{2}$ não percebe o homem fora de sua malha social. Um homem em ação, falante do mundo e falante de si mesmo. A linguagem como soberana do homem, tem o poder de falar do próprio homem, dando ordens a ele. Assim, a linguagem passa a ser um mapa aberto, conectável em todas as dimensões e pode estar sempre mudando de paisagem, vazando por todos os lados. A linguagem não é fixa é sim, uma

\footnotetext{
${ }^{1}$ É válido ressaltar que no volume II de Mil Platôs: capitalismo esquizofrenia, Deleuze-Guattari pensam o regime de signos por outro viés que não mais a do Signo em Proust e os Signos. Em Proust e os Signos Deleuze levanta questões que são da natureza da arte e aqui, o autor já leva a discussão para a linguagem. Por isso que é importante sermos cuidadosos em mostrarmos de qual Deleuze estamos falando.

2 Tratando-se da leitura que Benveniste faz de Austin, devemos tomar cuidados, pois quando Benveniste em seus Problemas de Linguística Geral I discute a natureza da filosofia analítica e a linguagem, ele confronta sua posição com a de Austin quando diz: "Apresenta-se assim a ocasião de estender e de precisar a nossa própria visão confrontando-a com a de J.L. Austin" (p. 299). Segundo Benveniste, certos performativos parecem não significar mais nada hoje em dia, pois "tanto as banalizou a vida social", caindo em nível de simples fórmulas ainda mais banais, como dizer "bom dia", "desejo-lhe um bom dia", é um exemplo de performativo de "intenção mágica", que segundo Benveniste perdeu a sua solenidade e a sua virtude primitivas.
} 
realizadora de atos de fala. Mas, afinal, em que consiste a natureza do ato de fala? Para isso, Austin nos apresenta uma espécie de "delimitação preliminar do performativo" que, através de sentenças como "aceito (scilicet), esta mulher como legítima esposa" (AUSTIN, 1990, p. 24), não estamos, nesse ato de fala, descrevendo um ato (dizendo) e sim, fazendo, casando, pois quando digo diante do juiz ou no altar, "aceito", não estou relatando um casamento, estou me casando. Ou seja, o ato de fala alcança a performatividade quando implica uma ação, pois ao emitir algum tipo de proferimento, realiza-se uma ação. Em outras palavras, é inerente ao ato de fala, ou ao performativo, um certo caráter ficcional, pois existe um "como se" no ato de fala. Daí, se ao dizer, não estou praticando e nem descrevendo e sim, fazendo algo. No entanto, o ato de fala não deixa de ser uma ficção, uma performance que deve ser proferida em um determinado lugar, em uma determinada data e hora, como um "acontecimento", um "evento", tendo, por sua vez, uma natureza única. Por isso, sendo um ato, o enunciado performativo possui uma propriedade de ser único. Quando declaramos diante do juiz ou diante do padre uma certa sentença, estamos não apenas declarando publicamente algo, como estamos fazendo e, com esta ação, estamos provocando um certo efeito que não é de natureza semântica, mas sim, de natureza política, pois o ato de fala nos faz ver no mundo e somos vistos no mundo de forma diferente. O "aceito" da noiva diante do juiz, a declaração de que um determinado calouro foi aprovado no vestibular, ou o ato de fala do orientador, juntamente com os conceitos que todos os componentes da banca de defesa de tese deram publicamente, são performativos capazes de provocar um efeito não apenas na vida dos respectivos declarados, como, inclusive, das pessoas envolvidas no ato. Sendo assim, existe um caráter ético e político da anunciação do ato de fala. Por isso, essa questão da "responsabilidade decorrente de uma ação" é essencial no método de análise de Austin e será de fundamental importância na formação do pensamento linguístico e filosófico de Deleuze \& Guattari.

Mas como devemos fazer para termos êxito em uma determinada ação? Austin, na II Conferência nos fala das "Condições para performativos felizes". Segundo ele, para termos sucesso diante de certos performativos, além de 
proferirmos palavras chamadas performativas, muitas outras coisas em geral têm que ocorrer de modo adequado para podermos dizer que realizamos com êxito a nossa ação. Nos parece óbvio, pois sabemos que se não formos bem em uma defesa de tese, ou seja, se a tese não estiver de acordo com as exigências da banca, ou se não tivermos de acordo com as normas da instituição, como insuficiência de créditos, ou algo do gênero, podemos não gozar de um performativo feliz. Assim, se não é declarado publicamente que uma determinada pessoa já é doutora, essa ausência de performatividade vai impedir com que essa pessoa tente concurso para o nível de doutoramento e com isso, não poderá gozar de um cargo que tenha a exigência de titulação de doutor. No entanto, a falta do ato de fala, desse "como se", impede com que alguém se faça (ação) doutor. Um exemplo clássico dado por Austin é relacionado ao casamento:

[...] se as pessoas não estão em posição de realizar o ato seja porque, por exemplo, já são casadas, seja porque foi ao comissário e não o capitão do navio quem realizou o casamento, então o ato em questão (o casamento) não se realiza com êxito, não se efetua, não se concretiza (AUSTIN, 1990, p. 31).

$\mathrm{Na}$ ótica austiana quando não se é sincero no ato, realizou-se um desrespeito ao procedimento. Segundo ele, para que haja uma performatividade feliz, devese obedecer a um procedimento aceito convencionalmente para que apresente um determinado "efeito convencional", incluindo o proferimento de "certas palavras", por "certas pessoas" em "certas circunstâncias", devendo essas pessoas e circunstâncias particulares, serem adequadas ao procedimento específico invocado, sendo de responsabilidade (caráter ético da performatividade) de todos os participantes a agirem de modo correto e completo, envolvendo os pensamentos e os sentimentos dessas personas. Os participantes envolvidos no "proferimento performativo" ou na "sentença performativa" devem estar proferindo uma carga de intencionalidade sincera e ética para que o performativo seja conduzido de forma adequada.

Do contrário, Austin nos adverte acerca de algumas "infelicidades" diante dos proferimentos performativos que ele classifica dualmente como explícitos e 
implícitos. Ele dá um exemplo mostrando uma situação em que ao escolher um parceiro para um determinado jogo e digo, escolho fulano e esse fulano retruca dizendo que não vai jogar, na ótica austiana, houve uma situação infeliz. No entanto, a regra de gramática, como um marcador de poder, não deixa de ser uma prodigiosa máquina emissora de proferimentos performativos. Assim, a coordenada semiótica gira em torno de ordens. Por isso, Austin dá o exemplo do imperativo "vá". São ordens desse tipo que Deleuze e Guattari retomam ao dizerem "pronto", "sim" ou "vamos". São apoiados nessa concepção que Deleuze e Guattari afirmam que "Uma regra de gramática é um marcador de, antes de ser um marcador sintático" (DELEUZE; GUATTARI, 1995, p.12), além dos maus usos envolvendo sentimentos, pensamentos e intenções como "declaro-me inocente" ou "Eu o absolvo" quando creio que a pessoa é culpada (pensamento); quando há um tipo de performativo como "meus pêsames", dito sem qualquer sentimento de solidariedade (sentimento); ou mais ainda, "prometo", dito sem intenção de fazer o que se prometeu, ou declaro guerra dito quando não tenho a intenção de lutar( intenções). Esses são alguns exemplos de performativos apontados por Austin e podemos voltar a uma pergunta feita por ele na primeira conferência como " pode o dizer realizar o ato?".

Em outras palavras, a pragmática como eixo ordenador da política da língua nos arrasta para uma semiótica esquizofrênica profundamente marcada para um enfrentamento da maneira de fazer a língua vibrar de uma outra maneira. Penso que a contribuição de Deleuze \& Guattari no que diz respeito à Filosofia da linguagem e á linguística não está em acordar a teoria dos atos de fala de Austin, nem em mexer o caldeirão da infraestrutura e da superestrutura, pois penso não ser mais interessante a ideia um pouco óbvia de que a subjetividade é polifônica. O interessante aqui é percebermos que é fundamentalmente necessário driblar qualquer código da tradição linguística e apelarmos para o modo expressivo da linguagem. Fazer dela um estilo de vida. Não parece ser mais necessário falar de um lado que a língua tem um caráter social e do outro lado, que a fala é uma realização por parte do indivíduo. Interessa sim, fazer dessa língua um aberto mapa de intensidades. Mas para isso, precisamos 
deixar a língua vibrar de uma outra maneira e fazer dela uma máquina de guerra de tal forma que ela esteja além da comunicação e da informação. Assim, podemos entrar em uma corrente de variação contínua da linguagem, saindo dos limites impostos pelas coordenadas semióticas e pela imponência da sintaxe. A aventura de quem escreve começa quando, para além da sintaxe, saímos dos sulcos costumeiros da linguagem e fazemos da língua um elemento fundamentalmente expressivo no mundo. É entrando nessa máquina abstrata da língua e enlouquecendo com ela que se pode utilizar a linguagem para obedecer e fazer obedecer e não acreditar nela.

Devemos sim, nessa política da língua, usar a linguagem indiretamente, pois o discurso indireto não se separa desse "ouvir dizer" da linguagem. O convite de Deleuze \& Guattari é para fazer da linguagem um estilo de vida, onde seu abrigo, sua morada somente passa a existir quando abrigamos nela de forma indireta. É a travessia de quem escreve torcendo e destorcendo a linguagem, criando uma nova língua dentro da nossa língua, diria Proust, uma espécie de língua estrangeira, de algum modo. O regime semiótico se dá na linguagem criativa, embaralhada. A semiótica é a luta com a língua em des/vio constante diante das normas impostas pela gramática. Assim, Deleuze \& Guattari criam aquilo que Júlia Almeida (2003) chama em seus Estudos Deleuzeanos da Linguagem de "teatro da língua", mas um teatro que não se fixa em uma regra marcada por eixos sincrônicos e diacrônicos e muito menos se prende a sintagmas verbais e nominais, tendo a frase presa a uma diagramação arbórea, marcada por certas limitações da gramática sintagmática. O que temos em termos linguísticos é uma pragmática semiótica que tem como pressuposto político a máquina abstrata que está além dos signos. O problema da linguagem em Deleuze é carregado de uma profunda influência da ação, pois os atos de fala ou sua performatividade fazem a gramática vazar criando sempre novos mapas de intensidades linguísticas, dentro de uma malha intersubjetiva que faz existir o mundo que é movido por palavras de ordem e atos de fala. A cisão entre linguagem e mundo deixa de existir porque só é possível criar essas zonas de intensidades linguísticas quando, ao dizer, fazemos algo. Desse modo, a ação existe somente pelo fato dos perform 
agirem eticamente em seus proferimentos. Assim, Deleuze \& Guattari não pretendem criar uma regra de gramática, pois não podemos pensar uma gramática deleuzena. Creio que eles têm pavor disso e não é gratuito que eles fazem um ataque à gramática com toda sua dualidade desde o começo. O que Ihes interessa de fato, na trilha de Austin, é uma nova revirada linguística capaz de criar novos postulados movidos pela soberania da linguagem, pois no fundo no fundo, eles querem dizer que em todos os lados que estivermos, estaremos sempre a serviço da linguagem, sendo guiados por ela, ouvindo suas ordens, escutando e aguardando-as.

Dito de outra maneira, Deleuze sempre demonstrou um profundo interesse pela discussão literária, pela ciência e pela arte. Ele se diferencia da maioria dos filósofos da tradição do pensamento por manter vivo um diálogo que vai se formando como um rizoma que vai florescendo para todos os lados. Em termos de linguagem, seu valor está em falar de uma máquina abstrata da língua que revela a cada instante um devir revolucionário dentro da própria língua, acabando com as dicotomias, fazendo o discurso direto banhar constantemente no discurso indireto, nos mostrando assim, que falar da linguagem é nos envolver em uma teia de aranha que vai se embaralhando nela mesma e, nessa embaralhada língua, nós somos arrastados por ela e por toda complexa malha que povoa o universo linguístico.

\section{Considerações finais}

Sem dúvida, a noção de gagueira em Deleuze é de fundamental importância para se compreender a noção de poesia e escritura da Diferença, tendo como vizinhança a linguagem e os múltiplos signos emitidos pela máquina literária. A escritura, como forma de pensamento no próprio pensamento tem sua gênese no processo de criação e recriação da vida. A linguagem e a vida formam uma corrente contínua. Ser gago da sua língua significa fazer dela uma língua estranha, de algum modo, estrangeira, pretendia Proust. É da Recherche que Deleuze se deslumbra o conceito de signo, pois para ele, o aprendizado está relacionado à decifração e interpretação dos signos ou hieróglifos. É diante 
dessa força que vem de fora e rouba a paz que a Literatura produz sentidos. $O$ leitmotiv do Tempo Redescoberto é a palavra forçar. Isso por que, "perder tempo" é o móbil da Diferença pois perder significa se redescobrir no âmago do Tempo perdido. Essa é a verdadeira eternidade da arte. Todos os signos sejam eles mundanos, amorosos e ciumentos convergem na Arte.

Deleuze é um gago da Diferença na medida em que arrasta o pensamento para fora dos sulcos costumeiros da linguagem e faz a língua delirar. A Literatura como delírio faz do escritor-ouvidor, um maldito, portanto malvisto da linguagem e da vida. $O$ charme de quem escreve é sua potência, sua vitalidade, sua capacidade de dizer sempre "sim". Quem não tem charme não tem vida. É esse charme a própria escritura. Experimentar o desastre é se encontrar com uma experiência-limite da linguagem que se dá nessa zona de vizinhança e indiscernibilidade com o pensamento. A escritura gaga é desastrosa por excelência por que revela seu fora mais dentro que o próprio dentro. É no desastre que a linguagem se duplica e é arrastada ao infinito. $O$ desastre é o estado clínico da gagueira da escritura.

Em outras palavras, Gilles Deleuze teve várias experiências literárias. A relação que ele teve com Proust foi, certamente, uma relação do tipo "curto circuito", um "efeito elétrico" no encontro e com o arrombamento do pensamento. A máquina literária de Proust provocou em Deleuze uma "exaltação nervosa" uma vez que a violência do signo veio como uma necessidade assim como a emergência da Literatura é o pensamento. E a emergência do pensamento é a linguagem. Linguagem e Pensamento formam um platô que se deságua na margem da Escritura. Assim, a vida ativa 0 pensamento e o pensamento, por sua vez, afirma a vida. É essa atividade plástica do pensamento que fez Deleuze e, certamente Foucault, duplicar a linguagem ao infinito. 


\section{POETRY: A "WAR MACHINE" THOUGHT}

ABSTRACT: This article articulates a reflection on poetry as thinking machine, once the poetic art slips in language and multiples signs of art and strength and thought. Thus, reading Deleuze, philosopher of difference, I'm looking for some rhizomic and virtual contamination to thereafter discuss poetry as an activator and as a potency of thought and the stuttering language of the poet. Thinking about poetry and Philosophy of Difference in transit means establish a prolific dialogue with the stuttering language of Gilles Deleuze. Writing about Deleuzian's thought involves some dancing on the politics of subjectivity, the creation and reinvention of life. It also involves mapping a literary experience with Marcel Proust and the nature of the Zodiac. The literature machine is stutter insofar that machine drags the thought out of the grooves customary language leading it to delirium. The experience with the literary language is in that occur stutter that makes each writer-poet as a foreign of his own language. The stutter is the charm of the scripture and the becoming-writer. Without charm there is no life and there is no Difference. The power of Difference is the poetry in transit with thought and language and that is a war machine of thought.

KEYWORDS: Thought. Sign. Difference. Stuttering. Poetry.

\section{REFERÊNCIAS}

ALMEIDA, Julia. Estudos deleuzeanos da linguagem. Campinas: Editora da Unicamp, 2003.

ARTAUD, Antonin. O Teatro e seu duplo. São Paulo: Martins Fontes, 2006. Linguagem e vida. São Paulo: Perspectiva, 2008.

AUSTIN, J.L. Quando Dizer é Fazer Palavras e Ação. Porto Alegre: Artes Médicas, 1990.

BARTHES, Roland. O rumor da língua. São Paulo: Martins Fontes, 2004.

BEVENISTE, E. Problemas de Linguística Geral 1. São Paulo: Pontes Editora da Universidade de Campinas, 1991.

BLANCHOT, Maurice. A Conversa infinita. São Paulo: Escuta, 2001.

DELEUZE, Gilles. Crítica e Clinica. São Paulo: Editora 34, 1997.

Proust e os Signos. Rio de Janeiro: Forense Universitária, 2003.

Diálogos. São Paulo: Escuta, 1998.

DELEUZE Gilles; GUATTARI, Felix. Kafka para uma literatura menor. Lisboa: Assírio \& Alvim, 2002.

Mil Platôs: capitalismo e esquizofrenia. Rio de Janeiro: Editora 34,

1995.

Texto Digital, Florianópolis, v. 9, n. 1, p. 68-94, jan./jul. 2013. ISSNe: 1807-9288 
DERRIDA, Jacques. A Escritura e a Diferença. Rio de Janeiro: Perspectiva, 2002.

EYBEN, Piero. Senão, ctônica, escritura: verdade e negrume. In: DERRIDA, Jacques. Escritura \& Diferença: no limite ético-estético. Piero Eyben e Fabrícia Walace Rodrigues (Org.). Vinhedo: Horizonte, 2012.

FOUCAULT, Michel. Estética: literatura e pintura, música e cinema. Rio de Janeiro: Forense Universitária, 2006.

PROUST, Marcel. Contre Sante-Beuve: notas sobre crítica e literatura. São Paulo: lluminuras, 1998.

Texto enviado em maio de 2013.

Texto aprovado em julho de 2013. 